\title{
Alterations on piscivorous diet following change in abundance of prey after impoundment in a Neotropical river
}

\author{
Geuza Cantanhêde ${ }^{1}$, Norma Segatti Hahn ${ }^{1,2}$, Rosemara Fugi and Éder André Gubiani ${ }^{1}$
}

The goal of this study was to investigate the alterations of diet of a piscivorous fish (Acestrorhynchus pantaneiro) following changes in abundance of a forage fish (Moenkhausia dichroura) during the trophic upsurge stage in a reservoir. Fish samplings were taken monthly in the Manso Reservoir (State of Mato Grosso, Brazil) from March 2000 to February 2001 (period I) and from March 2003 to February 2004 (period II). The abundance of Moenkhausia dichroura in the reservoir was significantly different in both periods, representing $9.6 \%$ of the individuals in period I and $66.4 \%$ in period II. Stomach contents analyses showed that the number of prey species consumed by $A$. pantaneiro decreased from 41 prey in period I to 14 in period II. In the last period M. dichroura was the most important prey, comprising $95 \%$ of the diet, in contrast with the period I when this species represented only $15 \%$ of the diet. The predator and prey size relationship was positive in both periods, however was significantly different, because small and large predators consumed mainly small prey (M. dichroura) in period II. Thus, the results showed that $A$. pantaneiro altered its diet composition, trophic niche breadth and prey sizes to feed on more abundant and accessible prey. These alterations probably caused a decrease in energy costs related to prey searching, maximizing the energy gain of the predator.

O objetivo deste estudo foi investigar alterações na dieta de um peixe piscívoro (Acestrorhynchus pantaneiro) após mudanças na abundância de um peixe forrageiro (Moenkhausia dichroura) durante a colonização de um reservatório. Os peixes foram amostrados mensalmente entre março/2000 e fevereiro/2001 (período I) e março/2003 e fevereiro/2004 (período II), no reservatório de Manso (Mato Grosso, Brasil). A abundância de $M$. dichroura foi significativamente diferente entre os períodos, representando $9,6 \%$ dos indivíduos no período I e $66,4 \%$ no período II. No período I A. pantaneiro consumiu 41 presas, enquanto que no período II foram registradas 14 presas, sendo que $M$. dichroura foi a presa mais consumida, passando a representar $95 \%$ da dieta, enquanto no período I representava apenas $15 \%$. A relação entre o tamanho do predador e da presa foi positiva em ambos os períodos, porém significativamente diferente. No período II pequenos e grandes predadores consumiram principalmente pequenas presas $(M$. dichroura). Os resultados mostraram que A. pantaneiro consumiu, no período II, a presa mais abundante e disponível, alterando a composição de sua dieta, amplitude do nicho alimentar e tamanho da presa. Estas alterações provavelmente causaram um decréscimo nos custos energéticos associados à procura da presa, maximizando o ganho de energia do predador.

Key words: Acestrorhynchus pantaneiro, Moenkhausia dichroura, prey-predator relationship, reservoir.

\section{Introduction}

Environmental changes resulting from hydroelectric undertakings, with the formation of large reservoirs, render local communities "unstable" mainly in the filling stage, with implications for the colonization of the new environment by the fish fauna (Agostinho et al., 1999, 2007). During the filling phase of a reservoir, the retention of nutrients, particularly those released by decaying submerged organic matter, is responsible for a marked increase in the system's biological production and a consequent increase in food supply (O'Brien, 1990; Williams \& Winemiller, 1998). Under these new conditions, fishes that show flexible reproductive and feeding strategies become more abundant (Fernando \& Holčík, 1991; Hahn et al., 1998; Ruiz, 1998; Agostinho et al., 1999; Albrecht \& Caramaschi, 2003; Agostinho et al., 2007).

According to Agostinho et al. $(1999,2007)$, an unavoid- able effect of impoundment on the aquatic fauna is a change in the composition and abundance of species, with depletion or even local extinction of some populations and the explosion of others, which find suitable conditions to proliferate. Environmental perturbations that subject a community to sudden changes in resource levels can provide insight into mechanisms structuring communities, such as competition for resources or predation (Piet, 1998).

It has been observed in several Brazilian reservoirs that small fish, which are able to complete their entire life cycle inside the reservoir (known as forage species), proliferate in the first years after impoundment (Agostinho et al., 1997; Hahn et al., 1998; Dias et al., 2005; Agostinho et al., 2007). Under these conditions, a marked increase in piscivorous species is expected to occur (Hahn et al., 1998; Agostinho et al., 1999; Luz-Agostinho et al., 2006), since their preferential food is widely available (Loureiro \& Hahn, 1996).

Experimental collections at the Manso Reservoir (State of

${ }^{1}$ Programa de Pós-Graduação em Ecologia de Ambientes Aquáticos Continentais, Universidade Estadual de Maringá, Av. Colombo, 5790, 87020-900 Maringá PR, Brazil. (GC) geuzac@yahoo.com.br

${ }^{2}$ Núcleo de Pesquisas em Limnologia, Ictiologia e Aqüicultura, Universidade Estadual de Maringá,Av. Colombo 5790, $87020-900$ Maringá, PR, Brazil. 
Mato Grosso, Brazil) showed a marked increase in captures of Moenkhausia dichroura (Kner, 1858) (A. A. Agostinho, unpubl. data), a small-sized characid (maximum length $=$ $9.0 \mathrm{~cm}$ ). It is a high fecundity species with an extended reproductive period and a short embryogenesis period, giving important advantage in the colonization process (Agostinho et al., 1999, 2007). Acestrorhynchus pantaneiro Menezes, 1992 (Acestrorhynchidae), a medium-sized species (maximum length $=35.0 \mathrm{~cm}$ ), was the most frequently captured piscivorous species in the reservoir all over the study period (A. A. Agostinho, unpubl. data).

Thus, the formation of this reservoir provided a unique opportunity, in a macro scale and under actual ecological conditions, to test several hypotheses regarding the predator-prey interactions. Although most piscivorous species consumed high diversity of prey (Popova, 1978; L'Abeé-Lund et al., 2002; Kahilainen \& Lehtonen, 2003), preference for a given prey depends on a set of factors, such as prey type, size, and abundance (Schoener, 1971; Griffiths, 1975; Popova, 1978; Garman \& Nielsen, 1982; L'Abeé-Lund et al., 1993; Amundsen, 1994; Floeter \& Temming, 2003; Kahilainen \& Lehtonen, 2003), predation risk, and competition (Milinski \& Heller, 1978; Gerking, 1994), among others. According to Gerking (1994) the overall objective of optimal foraging theory is to predict how animals can achieve a maximum net energy gain with the objective of maximizing lifetime reproductive success, or fitness.

In this study we analyzed data of $A$. pantaneiro diet from Manso Reservoir shortly after the filling phase of this reservoir (period I) and in the fourth year after the impoundment (period II). Using fish diet and the abundance of all fish species caught in both periods (especially $M$. dichroura) our aim was to investigate alterations in the diet composition, trophic niche breadth and prey sizes of a piscivorous fish after change in abundance of prey.

\section{Material and Methods}

\section{Study area}

Manso Reservoir (Fig. 1), formed in November 1999 (the filling stage was short - from November to February), was built on the Manso River (14 $32^{\prime}-15^{\circ} 40^{\prime} \mathrm{S}$ and $54^{\circ} 40^{\prime}$ $55^{\circ} 55^{\prime} \mathrm{W}$ ), in the Cuiabá River basin (State of Mato Grosso, Brazil). This is the most important river forming the Cuiabá River, which presents a dense drainage network and a regular rainfall regime and empties into the Pantanal of Mato Grosso, one of the largest wetlands of the world. The reservoir has an area of $427 \mathrm{~km}^{2}$. The main purpose of this reservoir is the generation of energy and regulation of flood and drought cycles, in order to protect large downstream cities.

\section{Fish sampling}

Fishes were sampled monthly from March 2000 to February 2001 (period I, shortly after the filling of reservoir) and from March 2003 to February 2004 (period II, four years after the impoundment), in six fixed sampling sites, distributed across the Manso Reservoir (Fig. 1). Fish were collected by a set of gillnets with different mesh sizes $(2.4,3,4,5,6,7$, $8,9,10,12,14,16,18 \mathrm{~cm}$, opposite knots). Nets were set simultaneously in open areas, littoral areas and bottom during $24 \mathrm{~h}$ and fishes were removed in the morning $(8: 00 \mathrm{~h})$, evening
$(16: 00 \mathrm{~h})$ and at night $(22: 00 \mathrm{~h})$. Fishing effort was the same in all sampling sites and during all study period.

Immediately after the capture fishes were identified and measured (standard length $\mathrm{cm}$ ) and a numerical scale was used to quantify the degree of stomach fullness in A. pantaneiro: $0=$ empty stomach, $1=0.25$ full, $2=0.5-0.75$ full and $3=$ completely full. Stomachs in degree 2 or 3 , representative of all months and periods, were preserved in $4 \%$ formalin for diet analysis. A total of 5993 stomachs of A. pantaneiro were examined, from which $85 \%$ were empty and $11 \%$ in degree 2 or 3 .

\section{Data analysis}

Abundance of all species was estimated, in both periods, by using the number of individuals caught in each of the six sampling sites. We did not used CPUE (number of individuals caught per $\mathrm{m}^{2}$ of net during 24 hours) as fishing effort at each sampling occasion was the same. To assess between periods differences (factor) in the abundance of $M$. dichroura (variable) and of other species (variable) a one-way ANOVA was applied. As two tests were performed with the results of the same data matrix, we applied a multivariate analysis of variance (MANOVA) to assess if the differences on the abundance were not randomly determined. If the MANOVA is significant, it indicates the appropriateness of using a one-way ANOVA for each variable separately (Johnson, 1998). The assumptions of normality and homoscedasticity were tested using Shapiro-Wilk and Levene tests, respectively. If assumptions of ANOVA were not met, we used a non-parametric equivalent test (Kruskal-Wallis test (Zar, 1999)).

Diet of A. pantaneiro was evaluated using the frequency of occurrence, numerical, and volumetric methods (Hyslop, 1980). These data were combined into the Index of Relative Importance (Pinkas et al., 1971):

$$
\mathrm{IRI}=(\% \mathrm{~N}+\% \mathrm{~V}) \% \mathrm{~F} * 100
$$

where, $\% \mathrm{~N}=$ numerical percentage, $\% \mathrm{~V}=$ volumetric percentage, $\% \mathrm{~F}=$ frequency of occurrence percentage.

In order to show the relative level of diet specialization, trophic niche breadth was estimated by Levin's Index (1968):

$$
\mathrm{B}=1 /\left(\sum_{j=1}^{n} \mathrm{p}_{\mathrm{j}}^{2}\right)
$$

where, $B=$ Levin's measured of niche breadth, $p_{i}=$ proportion of food item $\mathrm{j}$ in diet, $n=$ number of food items. Niche breadth values range from 1 to $\mathrm{n}$ where $\mathrm{n}$ is the number of categories of the resource, and higher values mean a wider use of the resource under consideration (Edds et al., 2002). In addition, food items were arranged in descending order of importance (rank-abundance patterns) in order to allow the simultaneous visualization of prey richness and equitability.

Standard length in centimeters for each prey was obtained, when possible, to assess the relationship between predator and prey size for each period. This relationship was investigated using a dispersion graph. The same predator length range in both periods was used. Data (standard length - Ls) were fitted by nonlinear regression analysis (quasi-Newton estimation methods) to the following model:

$$
\mathrm{L}_{\mathrm{S}} \text { prey }=\mathrm{a}^{*} \exp ^{\mathrm{b}^{*} \mathrm{~L}} \mathrm{~S}^{\mathrm{predator}}
$$


The model parameters were estimated using the Statisti$\mathrm{ca}^{\mathrm{TM}} 7.1$ software. Fitting quality was evaluated by the total variation explained by each model (in \%). Because these are nonlinear equations and their residues probably do not follow a normal distribution, the coefficient of determination $\left(\mathrm{R}^{2}\right)$ is not suitable for statistical tests. However, it can be used as an indicator of the portion of total variation explained by the model.

A covariance analysis (ANCOVA) was used to test the differences between the slopes of the straight lines obtained with the model (linearized) (Goldberg \& Scheiner, 1993). This analysis evaluates if size of consumed prey was different between periods, removing the predator size effect. Prey length was log-transformed. The explanatory variable, prey length, and the covariable, predator length, and the periods (I and II) were used as factors.

\section{Results}

In period I, $M$. dichroura represented only $9.66 \%$ of the abundance of all 102 species caught in the reservoir and it increased to $66.37 \%$ in period II when 89 species were caught (Fig. 2). According to the MANOVA, the effect of time was significant $(F=8.84 ; p=0.007)$. Thus, we applied an ANOVA for each variable separately. This alteration in $M$. dichroura abundance was highly significant according non-parametric analysis of variance $(\mathrm{H}=8.308 ; \mathrm{p}=0.0039$; assumptions of one-way ANOVA were not met; $\mathrm{p}<0.05)$. For all remaining species the differences of abundances between periods were not significant $(\mathrm{F}=0.005 ; \mathrm{p}=0.945)$.

The stomach contents of $469 \mathrm{~A}$. pantaneiro individuals were analyzed; prey could be identified in 314 of them (187 in period I and 127 in period II). The $A$. pantaneiro trophic niche breadth varied between periods I and II (Fig. 3). The highest breadth value was recorded in period $\mathrm{I}(\mathrm{B}=10.35)$, when the predator consumed a large number of prey items (41 prey species) (Fig. 3 ). The relative importance values for these items were low and indicate a low dominance of prey types. On the other hand, the trophic niche breadth was narrower in period II $(\mathrm{B}=1.10)$, as a reduction in the food spectrum (14 prey species) and a high dominance of one prey type were recorded (Fig. 3).

In period I, Apareiodon affinis, Characidium zebra, M. dichroura, and Astyanax abramis were the most important prey, even though each one represented only about $15 \%$ of the IRI. During period II, the diet changed and $M$. dichroura became the most important prey (IRI $=95 \%$ ) (Fig. 4).

Dispersion analysis revealed a positive relation between predator length and prey length, in both periods (Fig. 5 a-b). Fitted models were: $\mathrm{L}_{\mathrm{s}}$ prey $=0.8926^{*} \exp \left(0.0953^{*} \mathrm{~L}_{\mathrm{s}}{ }^{\text {predator }}\right)$ (period I) and $\mathrm{L}_{\mathrm{s}}$ prey $=1.6234 * \exp \left(0.0733^{*} \mathrm{~L}^{\text {predator }}\right)($ period II), and explained variance percentages for each model were $35 \%$ and $50.5 \%$, respectively. There was a significant difference in the size of $A$. pantaneiro prey between sampling periods (ANCOVA, $\mathrm{F}_{1 ; 368}=38.81 ; \mathrm{p}<0.05$ ). The smaller slope of the straight line in period II showed a high consumption

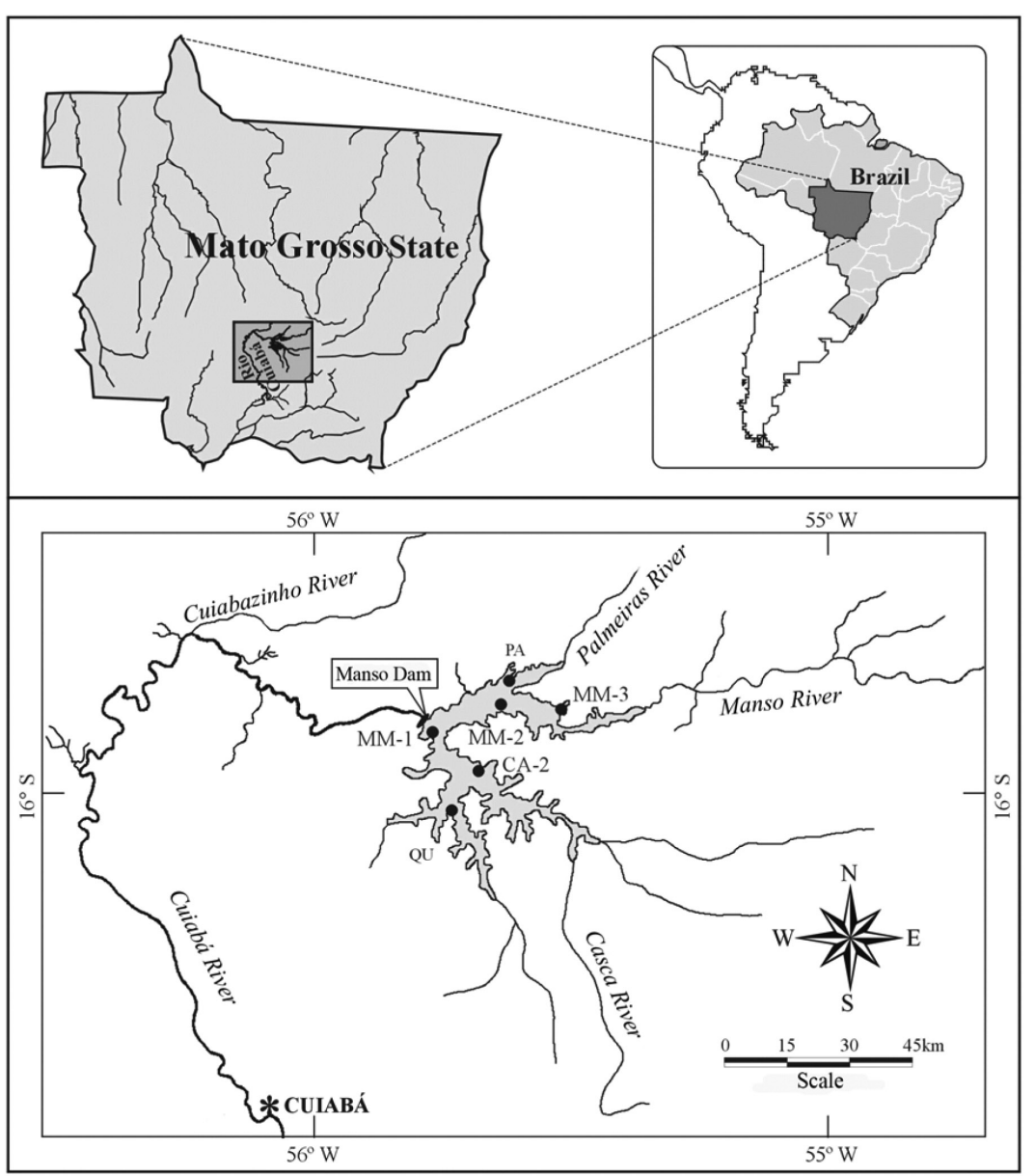

Fig. 1. Study area and location of sampling sites. of smaller prey and an intense predation of $M$. dichroura by $A$. pantaneiro, because predators of all lengths consumed this prey (Fig. 5b). In period I the maximum relative length of the ingested prey was about $78 \%$ of the predator size, while in period II they only reached $66 \%$ of the predator size.

\section{Discussion}

After impoundment of the Manso River, variations in the composition and structure of fish assemblages were observed during the first four years. Although a high abundance of fish was verified when compared with the basin's lotic environments, specific diversity decreased during that period, especially due to a high dominance of some species (A. A. Agostinho, unpubl. data). Among these, $M$. dichroura was numerically the most important, and $A$. pantaneiro was the third most captured species. According to Krebs (1994), dominance can be an important component in the organization of the community; however, this attribute is little known, and dominant species could be the focus of interactions that structure the community.

Shortly after the filling of the Manso Reservoir (period I), A. pantaneiro seems to have followed a feeding pattern commonly found in piscivorous fish, i.e., its diet consisted of a large diversity of prey items (Almeida et al., 1997; L'Abeé-Lund et al., 2002; Kahilainem 


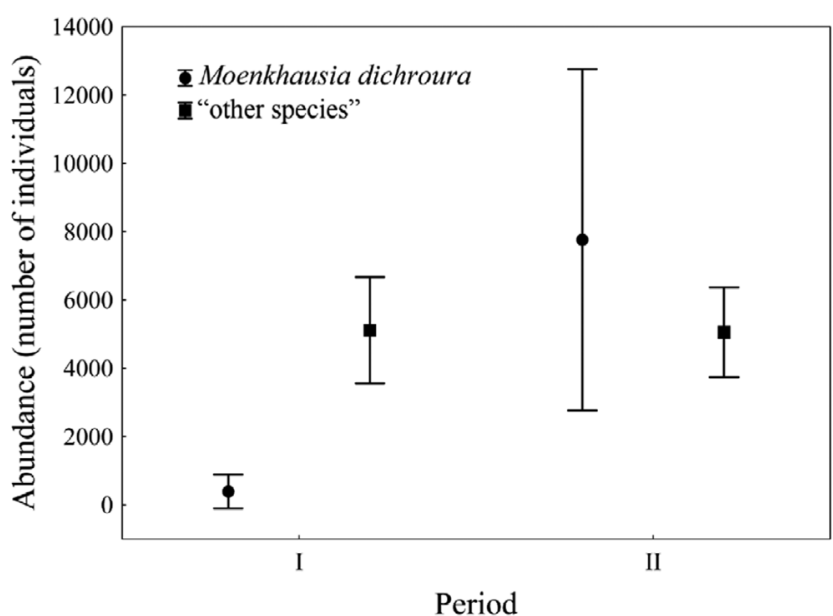

Fig. 2. Abundance of Moenkhausia dichroura and "other species" in the period I (From March 2000 to February 2001) and II (From March 2003 to February 2004), after impoundment of Manso River, Mato Grosso State, Brazil. Vertical bars represents the mean \pm S.D.

\& Lehtonen, 2003; Hahn et al., 2004). However, among the 41 prey species consumed, predation on only four of them $(A$. affinis, C. zebra, M. dichroura, and A. abramis) was important, corroborating conclusions by Popova (1978) that although predator fishes use a wide prey spectrum, the basic portion of feeding only includes a few species. The higher consumption of a few species has been associated especially with their abundance in the environment (Griffiths, 1975; Popova, 1978; Garman \& Nielsen, 1982; Amundsen, 1994; Edds et al., 2002; Floeter \& Temming, 2003). According to Griffiths (1975), all optimal diet theories suggest that when a strong dominance of prey fish species does not occur, a predator must take items proportionally to their abundances in the environment, feeding as number maximizers.

Four years after the impoundment, however, the high abundance of $M$. dichroura, which represented as much as $66.37 \%$ of the total number of fishes captured in the area, was certainly



Fig. 3. Dominance curve of prey items in the diet of Acestrorhynchus pantaneiro, based on Index of Relative Importance (IRI) in each sampling period at Manso Reservoir, Mato Grosso State, Brazil $(n=314 ; 187$-period I and 127-period II). $\mathrm{B}=$ trophic niche breadth.

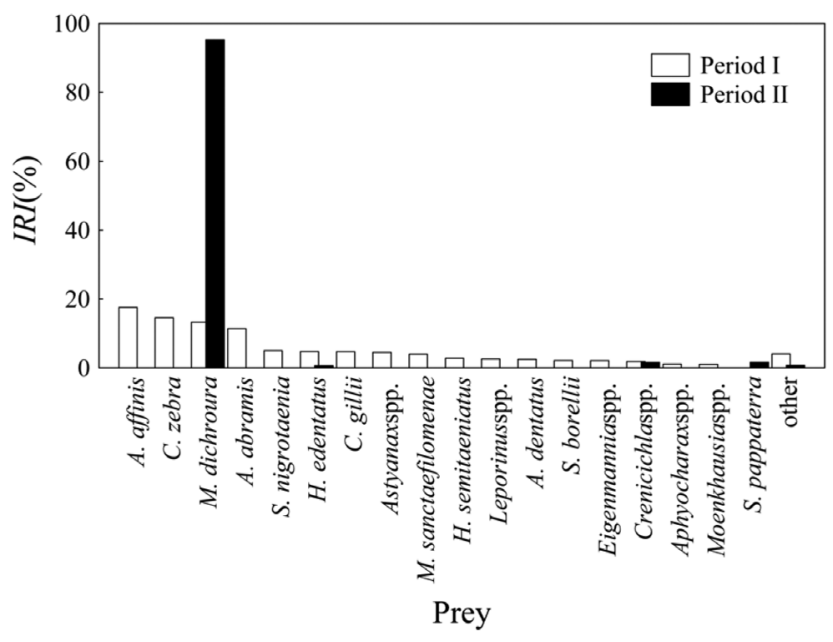

Fig. 4. Relative contribution (IRI) of prey fish in the diet of Acestrorhynchus pantaneiro in each sampling period at Manso Reservoir, Mato Grosso State, Brazil ( $\mathrm{n}=314$; 187-period I and 127- period II).

responsible for the alteration in the diet of $A$. pantaneiro. During that period, only 14 species were consumed, and $M$. dichroura represented $95 \%$ of the diet, showing high opportunism of the predator. In the Itaipu Reservoir, on the Paraná River basin, Hahn et al. (1997) recorded, for several years, a high constancy in number and biomass of the piscivorous species Plagioscion squamosissimus. The authors justified this fact due to an expressive proliferation of Hypophthalmus edentatus and Roeboides paranensis (= Roeboides descalvadensis), which sustained the species. In the Segredo Reservoir, on the Iguaçu River basin, Hoplias malabaricus and Oligosarcus longirostris were also considered opportunistic piscivorous species, since they fed especially on tetragonopterines, which dominated the environment after impoundment (Loureiro \& Hahn, 1996; Gealh \& Hahn, 1998). In the Guri Reservoir, in Venezuela, Cichla temensis fed predominantly on the three most abundant fish species in the littoral region of the reservoir (Williams \& Winemiller 1998), while in a reservoir in Norway, minnows, Phoxinus phoxinus showed a marked increase and were easily available to brown trout, Salmo trutta, a piscivorous species that was dominant in the environment (Aass, 1953 apud L'Abeé-Lund et al., 2002). After four years, minnows were found in $90 \%$ of the trout's stomach contents.

Prey size results showed a positive relation between $A$. pantaneiro length and the length of their prey in both periods, showing that the predator's energy demand increases as it grows in size, and larger prey become energetically more advantageous (Elliot \& Hurley, 2000). Acestrorhynchus pantaneiro utilized a wide range of prey length in period I, and their minimum size did not increase as rapidly as their maximum size. According to Popova (1978), it seems common among piscivorous fish that the minimum size of the ingested prey remains constant or increases slowly as the predator grows in size. Several studies have demonstrated that prey increase in size is associated with predator growth in piscivorous species (Popova, 1978; Amundsen, 1994; Almeida et al., 1997; Gealh \& Hahn, 1998; Little et al., 1998; Hahn et al., 2000; Esteves \& Pinto Lôbo, 2001; Kahilainen \& Lehtonen, 2003). Consequently, although larger 

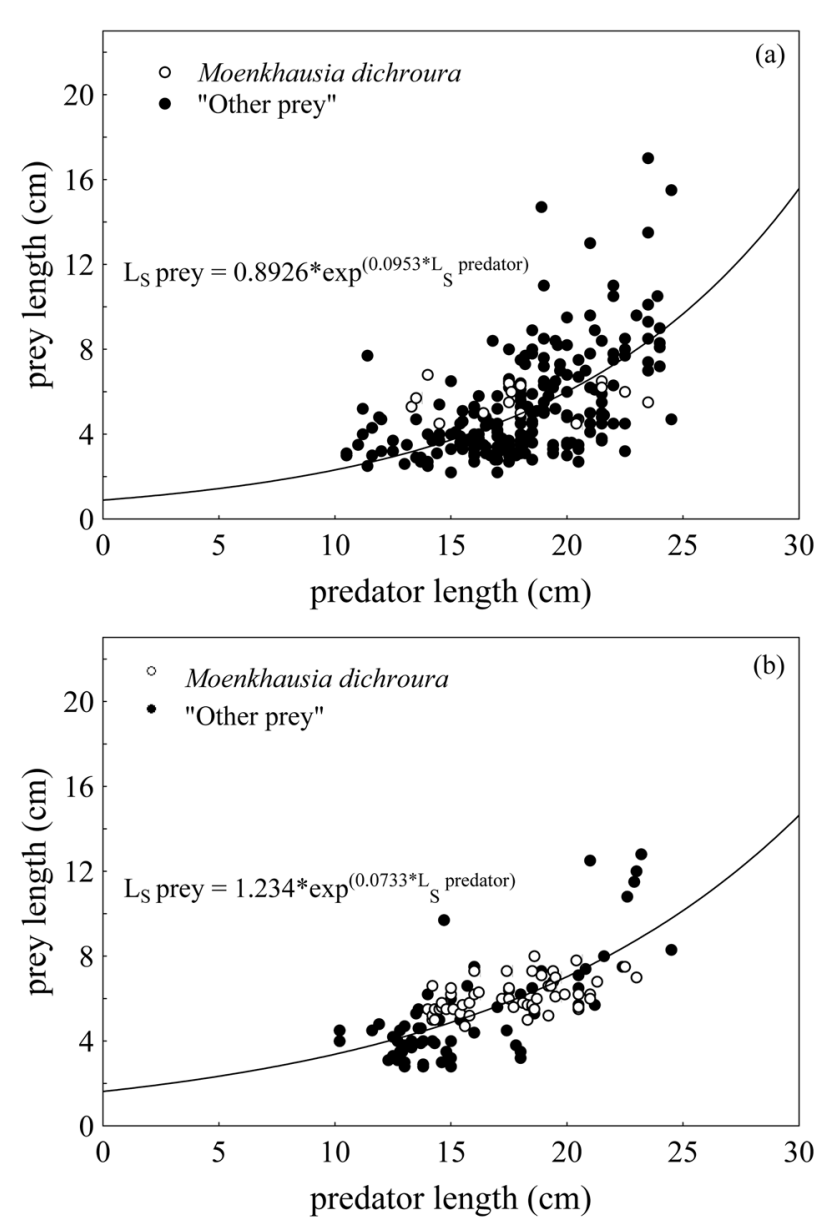

Fig. 5. Regression analysis between predator length (Acestrorhynchus pantaneiro) and prey length for sampling periods I (a) and II (b) at Manso Reservoir, Mato Grosso State, Brazil, followed by their respective equations fitted by the model (n $=379 ; 255$-period I and 124-period II).

A. pantaneiro individuals can feed on larger prey, since they have larger mouth openings, prey with small length continued to be preyed upon.

In period II, the maximum relative length of the ingested prey was about $66 \%$ of the predator size, while in period I they only reached $78 \%$ of the predator size. The reduction in the size spectrum of ingested prey in period II was attributed to the intense supply of $M$. dichroura in the environment, a forage species that did not grow beyond $9.0 \mathrm{~cm}$ in the reservoir. This fact considerably affected the predator-prey ratio, since this prey was commonly found in stomach contents, regardless of predator size. Pitcher \& Hart (1990) stated that the ingestion of small prey occurs due to their availability and ease of capture, energy costs resulting from this type of capture, or a reduction in the number of larger prey. The energy cost associated with searching, chasing, capturing, digesting, and assimilating prey (Winemiller, 1989) varies with their size: it is considered minimum for a certain size, increasing for larger or smaller prey (Griffiths, 1975). According to the optimal foraging theory, the predator makes to judgement between the energy and time required to travel to a large prey and that of capturing a nearer, smaller prey (Gerking, 1994). Although the consumption of smaller prey apparently seems to be detrimental to the cost/benefit balance, in A. pantaneiro it seems evident that predation on M. dichroura must have been compensated by the high density of this prey, which provided a higher encounter rate between both. According to Milinski \& Heller (1978), high prey densities allow the predator to attain a high predation rate because of the short distances between prey. As a result, the predator alter its diet to acquire prey that is very abundant and easily accessible, which leads to a considerable drop in food searching costs, an increase in food intake, and finally a maximization in energy gain. Our results confirm this statement since $A$. pantaneiro altered its diet concerning composition (essentially consuming the most abundant prey species), trophic niche breadth (decreasing the number of prey species and increasing the dominance) and prey lengths (increasing the consume of smaller preys than those defined by morphologic constraints) when one prey species dominated in the environment.

Admitting that predator species are practically the only available means to control the abundance of forage species that reach high densities during the first years after reservoir filling (Popova, 1978), piscivorous species such as A. pantaneiro may play an important role, allowing the coexistence of prey species and keeping their numbers below the level at which they would compete with one another for food or space (Paine, 1966). Consequently, by regulating the abundance of prey species, these piscivorous species can increase the stability of the ecosystem (Nikolsky, 1963; Popova, 1978).

\section{Acknowledgements}

We express our appreciation to Nupélia (Núcleo de Pesquisas em Limnologia, Ictiologia e Aqüicultura), to Furnas Centrais Elétricas and to PEA (Programa de Pós-graduação em Ecologia de Ambientes Aquáticos Continentais) for their financial support and infrastructure and CAPES (Coordenação de Aperfeiçoamento de Pessoal de Nível Superior) in terms of personal grants. We would like to thank Sidinei M. Thomaz for correcting the English and for helpful comments on the manuscript.

\section{Literature Cited}

Agostinho, A. A., L. M. Bini \& L. C. Gomes. 1997. Ecologia de comunidades de peixe da área de influência do reservatório de Segredo. Pp. 97-111. In: Agostinho, A. A. \& L. C. Gomes (Eds.). Reservatório de Segredo: bases ecológicas para o manejo. Maringá, EDUEM, 378p.

Agostinho, A. A., L. C. Gomes \& F. M. Pelicice. 2007. Ecologia e Manejo de Recursos Pesqueiros em reservatórios do Brasil. Maringá, EDUEM, 501p.

Agostinho, A. A., L. E. Miranda, L. M. Bini, L. C. Gomes, S. M. Thomaz \& H. I. Suzuki. 1999. Patterns of colonization in neotropical reservoirs, and prognoses on aging. Pp. 227-265. In: Tundisi, J. G. \& M. Straskraba (Eds.). Theoretical reservoir ecology and its applications. São Carlos, International Institute of Ecology, 585p.

Albrecht, M. P. \& E. P. Caramaschi. 2003. Feeding ecology of Leporinus friderici (Teleostei; Anostomidae) in the upper Tocantins river, central Brazil, before and after installation of a Hydroeletric Plant. Studies on Neotropical Fauna and Environment, 38: 33-40.

Almeida, V. L. L., N. S. Hahn \& A. E. A. M. Vazzoler. 1997. Feeding patterns in five predatory fishes of the high Paraná river floodplain (PR, Brazil). Ecology Freshwater Fishes, 6: 123-133. 
Amundsen, P.A. 1994. Piscivory and cannibalism in Artic Charr. Journal of Fish Biology, 45: 181-189.

Dias, R. M., D. Bailly, R. R. Antônio, H. I. Suzuki \& A. A. Agostinho. 2005. Colonization of the Corumbá Reservoir (Corumbá River, Paraná River Basin, Goiás State, Brazil) by the "lambari” Astyanax altiparanae (Tetragonopterinae; Characidae). Brazilian Archives of Biology and Technology, 48: 467-476.

Edds, D. R., W. J. Matthews \& F. P. Gelwick. 2002. Resource use by large catfishes in a reservoir: is there evidence for interactive segregation and innate differences? Journal of Fish Biology, 60: 739-750.

Elliott, J. M. \& M. A. Hurley. 2000. Optimum energy intake and gross efficiency of energy conversion for brown trout, Salmo trutta, feeding on invertebrates or fish. Freshwater Biology, 44: 605-615.

Esteves, K. E. \& A.V. Pinto Lôbo. 2001. Feeding pattern of Salminus maxillosus (Pisces, Characidae) at Cachoeira das Emas, MogiGuaçu river (São Paulo State, Southeast Brazil). Revista Brasileia de Zoologia, 61: 267-276.

Fernando, C. H. \& J. Holčík. 1991. Fish in reservoirs. Internationale Revue der gesamten Hydrobiologie, 76: 149-167.

Floeter, J. \& A. Temming. 2003. Explaining diet composition of North Sea cod (Gadus morhua): prey size preference vs. prey availability. Canadian Journal of Fisheries and Aquatic Sciences, 60: 140-150.

Garman, G. C. \& L. A. Nielsen. 1982. Piscivory by stocked brown trout (Salmo trutta) and its impacts on the nongame fish community of Bottom Creek, Virginia. Canadian Journal of Fisheries and Aquatic Sciences, 39: 863-993.

Gealh, A. M. \& N. S. Hahn. 1998. Alimentação de Oligosarcus longirostris Menezes \& Gèry (Osteichthyes, Acestrorhynchinae) do reservatório de Salto Segredo, Paraná, Brasil. Revista Brasileira de Zoologia, 15: 985-993.

Gerking, S. D. 1994. Feeding ecology of fish. San Diego, Academic Press, 416p.

Goldberg, D. E. \& S. M. Scheiner. 1993. ANOVA and ANCOVA: Field Competition Experiments. Pp. 69-93. In: S. M. Scheiner \& J. Gurevitch (Eds.). Design and Analysis of Ecological Experiments. New York, Chapman \& Hall, 445p.

Griffiths, D. 1975. Prey availability and food of predators. Ecology, 56: $1209-1214$.

Hahn, N. S., A. A. Agostinho \& R. Goiten. 1997. Feeding ecology of curvina Plagioscion squamosissimus (Heckel, 1840) (Osteichthyes, Perciformes) in the Itaipu reservoir and Porto Rico floodplain. Acta Limnologica Brasiliensia, 9: 11-22.

Hahn, N. S., A. A. Agostinho, L. C. Gomes \& L. M. Bini. 1998. Estrutura trófica da ictiofauna do reservatório de Itaipu (Paraná-Brasil) nos primeiros anos de sua formação. Interciência, 23: 299-305.

Hahn, N. S., R. L. Delariva \& V. E. Loureiro. 2000. Feeding of Acestrorhynchus lacustris (Characidae): a pos impoundment studies on Itaipu reservoir, upper Paraná river, PR. Brazilian Archives of Biology and Technology, 43: 207-213.

Hahn, N. S., R. Fugi \& I. F. Andrian. 2004. Trophic ecology of the fish assemblages. Pp. 247-59. In: Thomaz, S. M., A. A. Agostinho \& N. S. Hahn (Eds.). The upper Paraná river and its floodplain physical aspects, ecology and conservation. Leiden, Backhuys Publishers, 393p.

Hyslop, E. J. 1980. Stomach contents analysis - a review of methods and their applications. Journal of Fish Biology, 17: 411-429.

Johnson, D. E. 1998. Applied Multivariate Methods for Data Analysis. Pacific Grove, ITP.
Kahilainen, K. \& H. Lehtonen. 2003. Piscivory and prey selection of four predator species in a whitefish dominated subarctic lake. Journal of Fish Biology, 63: 659-672.

Krebs, C. J. 1994. Ecology: the experimental analysis of distribution and abundance. New York, Harper Collins College, 801p.

L'Abeé-Lund, J. H., P. Aass \& H. Saegrov. 2002. Long-term variation in piscivory in a brown trout population: effects of changes in available prey organisms. Ecology of Freshwater Fishes, 11: 260-269.

L'Abeé-Lund, J. H., A. Langeland, B. Jonsson \& O. Ugedal. 1993. Spatial segregation by age and size in Arctic charr: a trade-off between feeding possibility and risk of predation. Journal Animal Ecology, 62: 160-168.

Levins, R. 1968. Evolution in changing environments: some theoretical explorations. New Jersey Princeton University Press, 120p.

Little, A. S., W. M. Tonn, R. F. Tallman \& J. D. Reist. 1998. Seasonal variation in diet and trophic relationships within the fish communities of the lower Slave river, northwest territories, Canada. Environmental Biology of Fishes, 53: 429-445.

Loureiro, V. E. \& N. S. Hahn. 1996. Dieta e atividade alimentar da traíra Hoplias malabaricus (Bloch, 1794), nos primeiros anos de formação do reservatório de Segredo/PR. Acta Limnologica Brasiliensia, 8: 195-205.

Luz-Agostinho, K. D. G., L. M. Bini, R. Fugi, A. A. Agostinho \& H. F. Júlio Jr. 2006. Food spectrum and trophic structure of the ichthyofauna of Corumbá reservoir, Paraná river Basin, Brazil. Neotropical Ichthyology, 4: 61-68.

Milinski, M. \& R. Heller. 1978. Influence of a predator on the optimal foraging behaviour of sticklebacks (Gasterosteus aculeatus L.). Nature, 275: 643-644.

Nikolsky, G. V. 1963. The ecology of fishes. London, Academic Press, 352p.

O'Brien, W. J. 1990. Perspectives on fish in reservoir limnology. Pp. 209-225. In: Thornton, K. W., B. L. Kimmel \& F. E. Payne (Eds.). Reservoir limnology: ecological perspectives. New York, John Wiley, 246p.

Paine, R. T. 1966. Food web complexity and species diversity. American Naturalist, 100: 65-75.

Piet, G. J. 1998. Impact of environmental perturbation on a tropical fish community. Canadian Journal of Fisheries and Aquatic Sciences, 55: 1842-1853.

Pinkas, L., M. S. Oliphant \& I. L. K. Iverson. 1971. Food habits of albacore, bluefin tuna and bonito in California waters. Fish Bulletin, 152: 1-105.

Pitcher, T. J. \& P. J. B. Hart. 1990. Fisheries ecology. London, Croom Helm, 414p.

Popova, O. A. 1978. The role of predaceous fish in ecosystems. Pp. 215-249. In: Gerking, S. D. (Ed.). Ecology of Freshwater Fish Production. Oxford, Blackwell Scientific, 520p.

Ruiz, A. 1998. Fish species composition before and after construction of a reservoir on the Guadalete River (SW Spain). Archiv für Hydrobiologie, 142: 353-369.

Schoener, T. W. 1971. Theory of feeding strategies. Annual Review of Ecology and Systematics 2: 369-409.

Williams, J. D. \& K. O. Winemiller. 1998. Ecology and status of piscivores in Guri, an oligotrophic tropical reservoir. North American Journal of Fisheries Management, 18: 274-285.

Winemiller, K. O. 1989. Ontogenetic diet shifts and resource partitioning among piscivorous fishes in the Venezuelan llanos. Environmental Biology of Fishes, 26: 177-199.

Zar, J. H. 1999. Biostatistical analysis. New Jersey, Prentice Hall, 663p. 